\title{
Morphological development of Corydoras aff. paleatus (Siluriformes, Callichthyidae) and correlation with the emergence of motor and social behaviors
}

\author{
Daniel Rodríguez-Ithurralde, Gabriela del Puerto \& Fernando Fernández-Bornia
}

Laboratory of Molecular Neuroscience, Pharmacology and Developmental Toxicology

Instituto de Investigaciones Biológicas Clemente Estable (IIBCE), Av. Italia, 3318, 11600 Montevideo, Uruguay. (drodriguez@iibce.edu.uy; drithurralde@gmail.com)

\begin{abstract}
Here we examine major anatomical characteristics of Corydoras aff. paleatus (Jenyns, 1842) post-hatching development, in parallel with its neurobehavioral evolution. Eleutheroembryonic phase, 4.3-8.8 days post-fertilization (dpf); 4.3-6.4 mm standard length (SL) encompasses from hatching to transition to exogenous feeding. Protopterygiolarval phase (8.9-10.9 dpf; 6.5-6.7 mm SL) goes from feeding transition to the commencement of unpaired fin differentiation, which marks the start of pterygiolarval phase (11-33 dpf; 6.8-10.7 mm SL) defined by appearance of lepidotrichia in the dorsal part of the median finfold. This phase ends with the full detachment and differentiation of unpaired fins, events signaling the commencement of the juvenile period (34-60 dpf; 10.8-18.0 mm SL). Eleutheroembryonic phase focuses on hiding and differentiation of mechanosensory, chemosensory and central neural systems, crucial for supplying the larval period with efficient escape and nutrient detection-capture neurocircuits. Protopterygiolarval priorities include visual development and respiratory, digestive and hydrodynamic efficiencies. Pterygiolarval priorities change towards higher swimming efficacy, including carangiform and vertical swimming, necessary for the high social interaction typical of this species. At the end of the protopterygiolarval phase, simple resting and foraging aggregations are seen. Resting and foraging shoals grow in complexity and participant number during pterygiolarval phase, but particularly during juvenile period.
\end{abstract}

KEYWORDS. Catfish, developmental neuroethology, embryo, larvae, teleost.

RESUMEN. Desarrollo morfológico de Corydoras aff. paleatus (Siluriformes, Callichthyidae) y su correlación con la emergencia de sus comportamientos motores y sociales. Examinamos aquí las características anatómicas del desarrollo post-eclosión de Corydoras aff. paleatus (Jenyns, 1842), en paralelo con su evolución neuroetológica. La fase eleutheroembrionaria, 4.3-8.8 días post-fecundación (dpf), 4.3-6.4 mm de longitud estándar (SL), comprende desde la eclosión hasta la transición a alimentación exógena. La fase protopterygiolarval (8.9-10.9 dpf; 6.5-6.7 mm SL) va de aquella transición al comienzo de diferenciación de aletas impares, inicio de la fase pterygiolarval (15-33 dpf; 6.8-10.7 mm SL), definido por aparición de lepidotriquia en pliegue medial. Esta fase finaliza con la separación y diferenciación completa de aletas impares, que indican el inicio del período juvenil (34-60 dpf; 10.8-18.0 mm SL). La fase eleutheroembionaria prioriza el ocultamiento y la diferenciación de sistemas mecanosensoriales, quimiosensoriales y neurales cruciales para dotar a la larva de neurocircuitos eficientes de huída y detección-captura de nutrientes. La fase protopterygiolarval prioriza el desarrollo visual y la eficiencia respiratoria, digestiva e hidrodinámica. Las prioridades de la pterygiolarva cambian al aumento de la eficacia natatoria, adquiriendo el nado carangiforme y el ascenso vertical, imprescindibles para la alta interacción social característica de esta especie. Al fin de fase protopterigyolarval aparecen agrupamientos simples de reposo y forrajeo. Los shoalings de reposo y forrajeo crecen en complejidad y número de participantes durante la fase pterygiolarval y especialmente en el período juvenil.

PALABRAS-CLAVE. Bagre, embrión, larva, neuroetología del desarrollo, teleósteo.

Callichthyidae family harbors 197 valid species (BRITTO, 2003), grouped in eight genera; from that total, 156 species are included in Corydoras Lacépède, 1803, the Siluriformes genus comprising the highest number of species (Reis, 2003; Ferraris Jr., 2007; Tencatt et al., 2014). Corydoras representatives are widely distributed throughout all major river basins of South America (ShimabukuRo-Dias et al., 2004) and have relative economic importance among ornamental fish keepers (ReIs, 2003). Corydoras aff. paleatus (Jenyns, 1842) occupies slow moving, shallow streams along a wide geographical extension of Neotropical South America. Being a classical inhabitant of Río de la Plata (River Plate), Uruguay and Paraná river basins (BuRGESs, 1989), it also reaches colder climates, including, for instance Northern Patagonian rivers (BAIGÚN et al., 2002). They are usually observed in nature in various sizes of groups, from pairs to hundreds of fishes (BurGEss, 1989). They are benthic, though individuals occasionally surface to exchange a bubble of air, a behavior known as aeration, part of an adaptation that allows callichthyids to inhabit stagnant, anoxic waters (Kramer \& McCluRe, 1980).

Formally described long time ago, Corydoras aff. paleatus is found in almost every freshwater aquaria around the world, and despite of being of considerable developmental and ecotoxicological interest (SARIKAYA et al., 2004; Cazenave et al., 2006; Pesce et al., 2008; de Castilhos \& Cestari, 2013; Guiloski et al., 2013), scientific research on this species has been mainly devoted to molecular phylogeny and systematics (ShimabukURoDias et al., 2004), sound production (Pruzsinszky \& LAdich, 1998) and reproductive behavior (KHODA et al., 1995), but little is known on its morphological and neuroanatomical development. Moreover, although adult "peppered corys" are well known by amateur fish keepers for displaying a wide variety of ethological repertories, development of its individual and social behavior has received very little scientific interest. 
The aims of the present study were to establish the major phases of the morphological ontogenesis of Corydoras aff. paleatus, and to correlate them with the appearance of its main behavioral and socio-behavioral capacities.

\section{MATERIAL AND METHODS}

Breeding. Adult Corydoras aff. paleatus (46 males, 16 females.) of very good condition were obtained from a professional pet shop located in Montevideo, Uruguay. According to their records, the age of this first (parent) generation (on 15th-May-2011) was of 9-12 months. The age of the second generation, born at our laboratory, was determined with precision, since spawning occurred usually in the presence of laboratory personnel. Parent generation was distributed in five rectangular 85 -liter aquaria (70 cm x $32 \mathrm{~cm}$ x $38 \mathrm{~cm}$ ), at an approximate male:female ratio of 3:1, i.e., 9-10 males plus 3-4 females per tank. They were kept under a $14 \mathrm{~h}$ light-10h darkness cycle in a temperature-controlled $\left(23 \pm 0.5^{\circ} \mathrm{C}\right)$ room. Each tank was provided with a filtration system, water $\mathrm{pH}$ kept between $7.8-8.5$ and conductivity lower than $300 \mu \mathrm{S} / \mathrm{cm}$. Animals were fed daily with Tetramin tablets and Artemia salina nauplii. To induce spawning behavior, dry-season followed by rain season conditions were imitated as described by FuLLER (2001). Parents were moved from the reproduction tank immediately after ending the spawning cycle, and fertilized eggs kept in the spawning aquaria $\left(\right.$ at $23 \pm 0.5^{\circ} \mathrm{C}$ ) until 30 days upon hatching, having therefore each tank specimens of the same age.

Characterization of developmental periods and phases. For embryo-larval staging, period and phase definitions were used as stated in BALON $(1975,1999)$ and Belanger et al. (2010). Morphological terminology and criteria previously published by HUYSENTRUYT et al. (2009) for the related species Corydoras aeneus (Gill, 1858) were also used. Start of exogenous feeding was determined for each individual. Once two external feeding events were observed, individual fish was separated to a different tank and start of protopterygiolarval phase diagnosed. Initiation of the pterygiolarval phase was determined upon stereomicroscopic examination of unstained specimens (DurÁN et al., 2011), by the first appearance of actinotrichia and mesenchymatic buds of lepidotrichia within the median finfold (KAPOOR \& KHANNA, 2004).

In vivo stereo-photomicroscopy and microscopic biometry. Individuals aged from 5-23 days post fertilization (dpf) and $27 \mathrm{dpf}$ were measured alive (and in some cases photographed and filmed) under a stereomicroscope equipped with a high resolution camera, calibrated in micrometers $(\mu \mathrm{m})$. Specimens from 30-160 dpf (measured every five days), as well as 1, 1.5, 2, 2.5 and 3 year-old individuals were measured using a digital caliper to the nearest $\mathrm{mm}$ and/or with the stereomicroscope. For examining particular sense organs in alive specimens, a Nikon Eclipse E-300 microscope equipped with a high resolution camera was used. When immobilization was needed, fishes were mildly anaesthetized by immersion in aquarium water containing either tricaine methanesulfonate (3-aminobenzoic acid ethyl ester) at a final concentration of 135-150 mg per liter (Pistone et al., 2012).

Morphometrics of early development. The following body measurements, as shown in NovomesKá et al. (2013), were performed with a stereomicroscope and expressed in $\mathrm{mm}$ : standard length (SL), total length (TL), pre-orbital distance (POD), eye diameter (ED), head depth (HD), head length (HL), body depth (BD), preanal distance (PAD); predorsal distance (PDD) and pre-pelvic distance (PPD). Major horizontal diameter of the yolk sac was also done. Morphometrics data processing is explained at the end of this section.

In 5, 7, 9.5, 12, 20, 32, 60 and 75 dpf specimens, histological methods were employed to examine posthatching development of organ and tissue differentiation, with emphasis in age-dependent differences in both the structure of sense organs and the cytoarchitecure of central nervous system areas. Specimens were anesthetized and sacrificed as described (PISTONE et al., 2012) or anaesthetized and gradually fixed by minute increases of fixative concentration in the water surrounding the fish. Fixatives used were either 2-4\% paraformaldehyde in phosphate buffer ( $\mathrm{pH} 7.4), 4 \%$ formaldehyde or decalcifying-fixative mixtures described by RAMÓN y CAJAL \& DE CASTRO (1972). Some pieces were dehydrated, embedded in a paraffin-polyisobutylene mixture, sectioned at 4 or 9 $\mu \mathrm{m}$, and stained as described (RoDRíguez-ITHURRALDE et al., 1998). Whole specimens of same ages as above were processed in totum with silver impregnation methods (RAMÓN Y CAJAL \& DE CASTRO, 1972), embedded in Araldite and sectioned in a sliding microtome. Semithin sections of selected areas were stained with boraxic methylene blue. Some histological preparations were examined in an Olympus LX81 inverted optical microscope with Nomarski optics. An Olympus BX61 laser Confocal was employed for confocal imaging in some cases.

Recording and terminology of behavior and aggregation patterns. Fish behavior in the aquaria were recorded and photographed on a daily basis. In order to follow a systematic description of behavior, the nomenclature published by KaLuEFF et al. (2013) was used. Individual spacing was measured as mean nearestneighbor distance (fist-ray of dorsal to fist-ray of dorsal fin). Individuals that were moving or still, yet more than approximately four body lengths or more away from another group, were categorized as "alone moving" or "alone still/resting." Group behavior was classified as either "schooling”, "shoaling”, "shoal moving”, "shoal still”, “alone moving”, "alone still” or "aerating” (PITChER, 1983; KALUEFF et al., 2013). Fish groups were classified based on distances among neighboring individuals. Schools and shoals were identified by groups of fish that were located within a few body lengths of one or more other fish. The moving groups with the highest cohesion were classified 
as "schools". These groups were polarized, synchronized and neighbors were spaced approximately less than two body lengths apart from each other. A school is defined as a polarized and synchronized swimming shoal, whereas a shoal is a loose organization of fish (Pitcher, 1983) in which individuals are spaced more than a few body lengths from their shoal-mates, are less parallel with their neighbors relative to schools, and may be moving or still (Pitcher \& Parish, 1993). Groups that were loosely organized and actively moving were defined as "moving shoals." In these groups, neighbors were spaced between two to four body lengths apart, and were less polarized or synchronized. Groups that were not moving, regardless of amount of cohesion among individuals, were classified as "still shoals".

Regression models and statistics. For some specific variables, possible ontogenic changes during species development were assessed by plotting morphometrics variables (response variables) against standard length and head length (explanatory variables) as applied in OLIveIRA et al. (2012) and their relations described by means of different regression models (KovÁcs et al., 1999). To select the best explanatory model the F-Test (SoKAL \& RoHLF, 1981) was applied, using a significance level of $p<0.05$ (Oliveira et al., 2012).

Voucher specimens. Voucher specimens fixed in formalin (10\%) were deposited and registered under unique serial numbers (ZVC-P 12481 and ZVC-P 12482), with supervision of its Curator, Dr. Marcelo Loureiro, at "Colección de Vertebrados (Peces) del Departamento de Vertebrados de la Facultad de Ciencias," Montevideo (UdelaR), Uruguay.

\section{RESULTS}

Courtship and reproductive behavior. About a week after the start of an artificial rain season (as described in methods), courtship behavior commenced. Briefly, one or more females performed quick, repetitive ascending vertical swimming in parallel to the tank wall, apparently applying suction to the glass. This usually attracted the interest of one to three males, which try to chase her. Both female's pelvic fins have already formed a shell-shaped pouch, which may or not contain eggs. Briefly, the males followed and passed the female and presented their abdominal sides in front of her mouth, until the female chose one male and adopted the "T-position" attaching her mouth to the male genital papilla, while the male rests quiet, almost perpendicular to the female. While she applied the mouth on the male genital region, female operculi were closed and a number of eggs dropped from the female's genital region into the pelvic pouch. After a short rest, females reassumed the glass cleaning task with the mouth, and soon deposited egg clutches on these cleaned glass areas. Egg groups were plane, each of the two to nine eggs was glued independently to the wall. Eggs were spherical, $1.61-1.83 \mathrm{~mm}$ in diameter, adhesive and -immediately after spawning- white in color. Fertilized eggs were kept at $23 \pm 0.5^{\circ} \mathrm{C}$ until hatching, i.e., after a mean period of $5.5 \pm 2.4 \mathrm{dpf}$ at that temperature.

General growth, maximal standard length and morphometrics. Corydoras aff. paleatus growth was represented as standard length \pm standard deviation (SL $\pm \mathrm{SD})$ as a function of age, expressed in dpf (Fig. 1). Evolution of morphometrics variables during development is shown in Tab. I, while relationships of some of these variables with standard length (SL) and head length (HL) along development are presented in Table II. The F-test applied to our morphometrics data did not allow to unequivocally discard the hypothesis which stands that isometric growth is the best model for explaining the important developmental changes in eye diameter, preorbital distance and head length (as referred to standard length) that we found during the evolution from early eleutheroembryo to protopterygiolarvae.

Morphological phases of development. Figures 2-7 illustrate individuals representative of eleutheroembryos, protopterygiolarvae, pterygiolarvae and juveniles, while figures 8-15 include photographs of eggs (Figs 8-9), eleutheroembryos (Figs 10-11), larvae (Figs 1214) and young adults (Fig. 15). Figures 16-20 present histological microphotographies at different ages. The eleutheroembryonic phase (5.4-6.4 mm SL) commenced with hatching (around 5.4 days post-fertilization at $23^{\circ} \mathrm{C}$ ), 4.1-6.5 dpf and lasted until 8.8-9.0 dpf, when transition to exogenous feeding occurs. At hatching, eleutheroembryos exhibited a yolk sac of 0.10-0.29 mm in diameter (Figs 2, 10,11 ), and its head was poorly differentiated, with very small development of upper face, eyes and peri-ophthalmic regions (Fig. 2). Pre-orbital distance was very short (Tab. I) and eye pigment absent. Until 10 dpf, only two pairs of barbels were present (Fig. 11, Tab. III). In individuals in which hatching events were directly observed, both oro-pharyngeal membrane and anal region remained

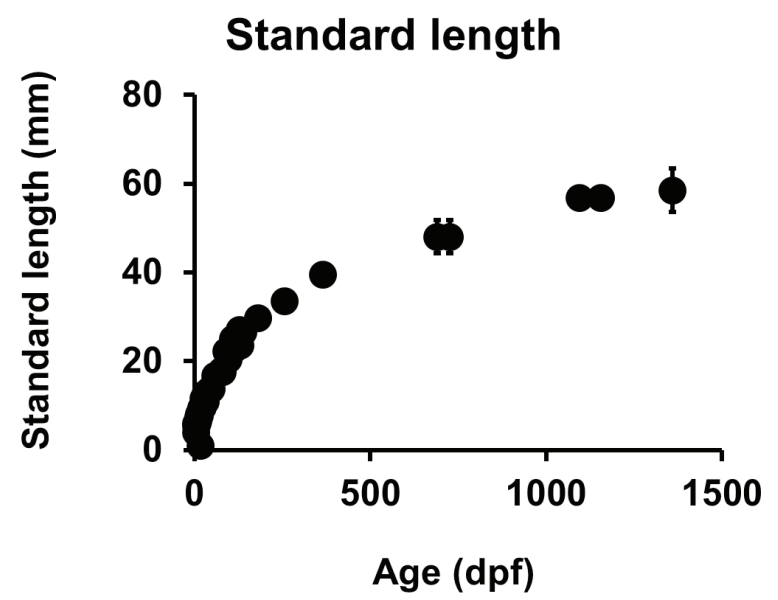

Fig. 1. Standard length (SL) of Corydoras aff. paleatus (Jenyns, 1842) as a function of age. Points represents mean SL \pm standard deviation (SD, in $\mathrm{mm}$ ) for each age group, expressed as days post-fertilization (dpf). 
unperforated until 10-15 hours after hatching. Until middle pterygiolarval phase, pectoral appendages were large, oval, skin folds devoid of mesenchymatic reinforcements (Figs 2-4, 10-12).

Protopterygiolarval phase (6.4-6.6 mm SL) occurred from 8.9 to $10.9-11 \mathrm{dpf}$ until appearance of lepidotrichia within the fin fold (Fig. 4). The continuous finfold constricted near the anus, whereas at the preanal region, a pair of pelvic fin folds could be noticed (Fig. 4). Between 8.9-9 dpf, mouth and anus were opened and larvae fed mainly from external sources (Tab. IV).

Pterygiolarval phase (6.6-12.7 mm SL, Figs 4-6, 14) went from 11-33 dpf, i.e., until the median finfold was entirely differentiated and no longer apparent (Figs 4-6). The early pterygiolarvae (11-14 dpf) exhibited external, asymmetrical gills with high blood flow and an almost
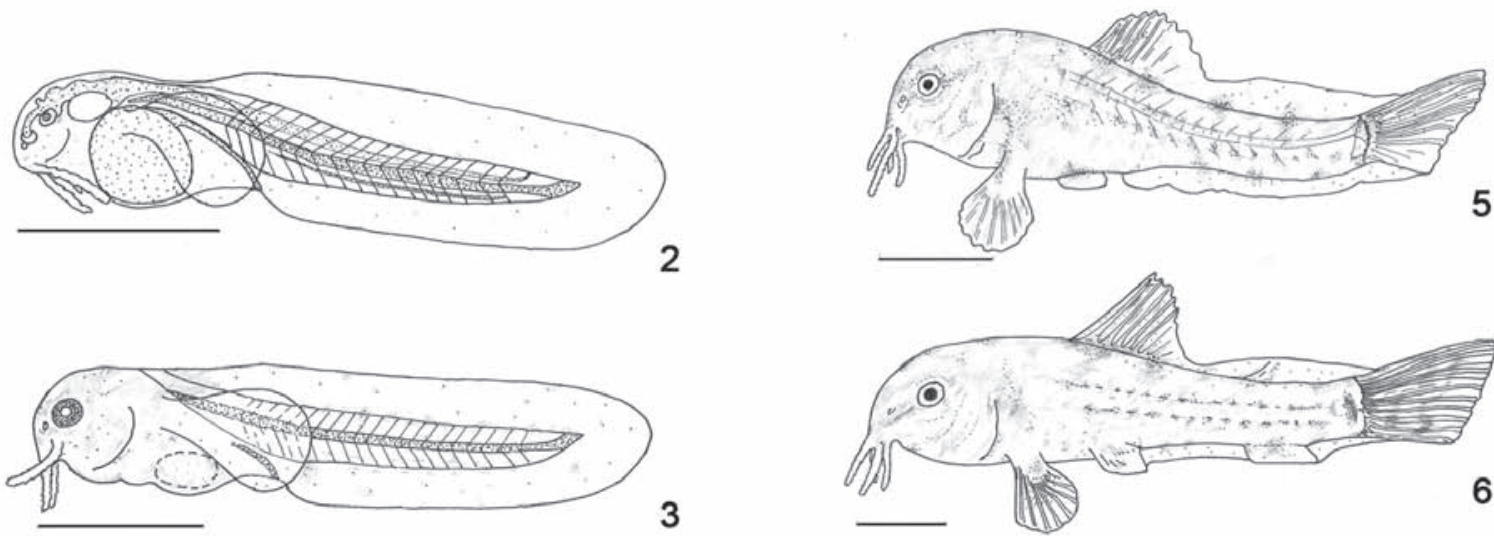

3

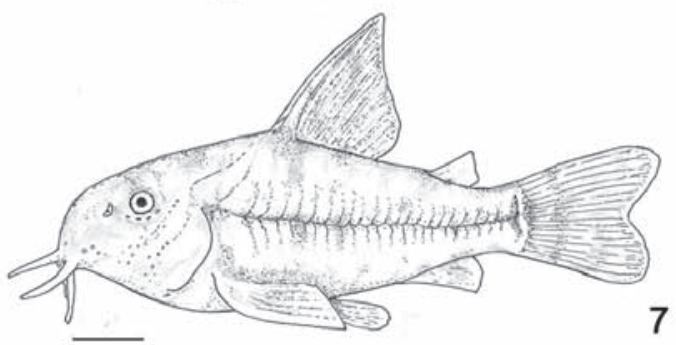

Figs 2-7. Corydoras aff. paleatus (Jenyns, 1842) morphology at defined phases and periods of development: 2, start of eleutheroembyonic phase, 5.4 days post-fertilization (dpf), 3 hours after hatching, $6.1 \mathrm{~mm}$ standard length (SL); 3, early protopterygiolarval phase (8.9 dpf, $6.5 \mathrm{~mm}$ SL); 4 , early pterygiolarval phase (11 dpf, $6.8 \mathrm{~mm} \mathrm{SL}$ ); 5, pterygiolarval phase (17 dpf, $8.8 \mathrm{~mm} \mathrm{SL})$; 6, late pterygiolarval phase (27 dpf, $10.1 \mathrm{~mm}$ SL); 7 , juvenile period (48 dpf, $14 \mathrm{~mm}$ SL). Scale bars, $2 \mathrm{~mm}$.

Tab. I. Values (mm) of minimal (Min) and maximal (Max) length, mean (x) and standard deviations (SD) found for morphometrics variables (BD, body depth; ED, eye diameter; HD, head depth; HL, head length; PAD, preanal distance; PDD, predorsal distance; POD, preorbital distance; PPD, prepelvic distance; SL standard length) from groups of Corydoras aff. paleatus (Jenyns, 1842) individuals (n, number of analyzed specimens) at a given developmental phase (EE, eleutheroembryo; IPL, initial pterygiolarval phase; LPL, late pterygiolarval phase; PP, protopterygiolarval phase). Absence of data in some columns is due to incomplete development.

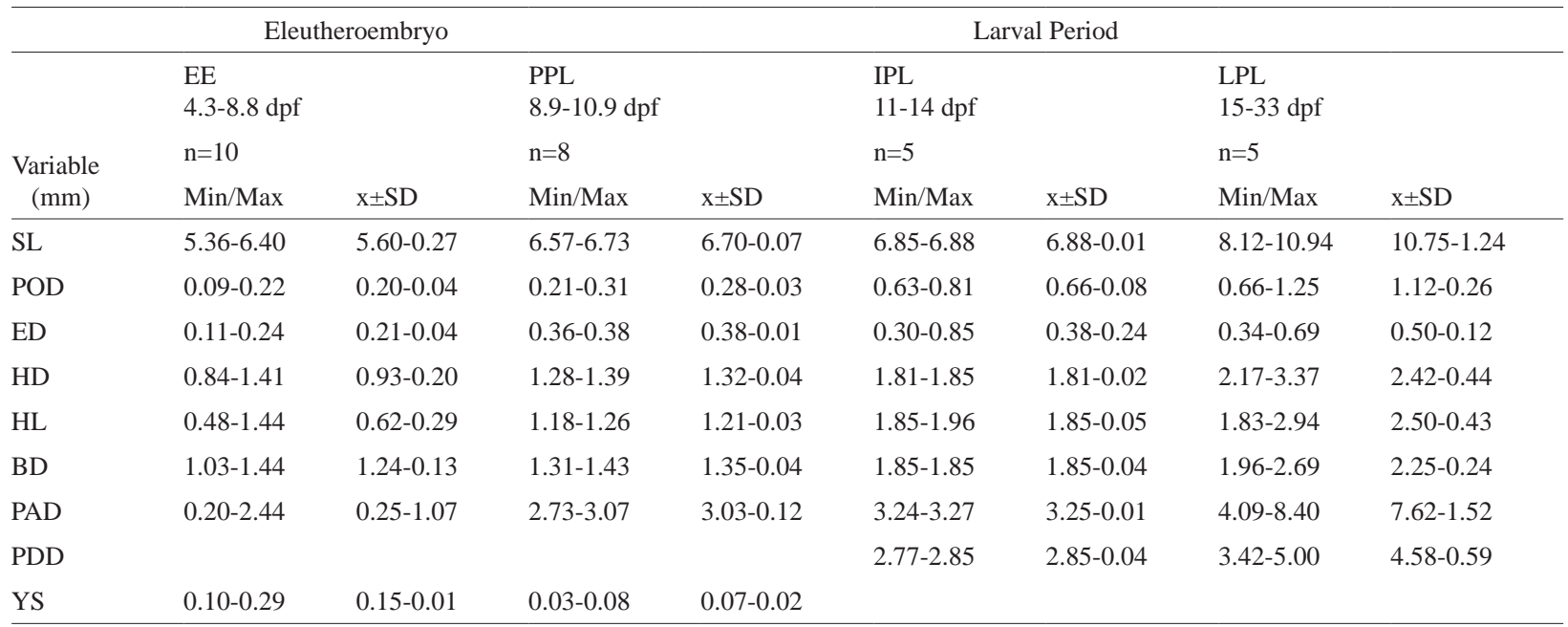



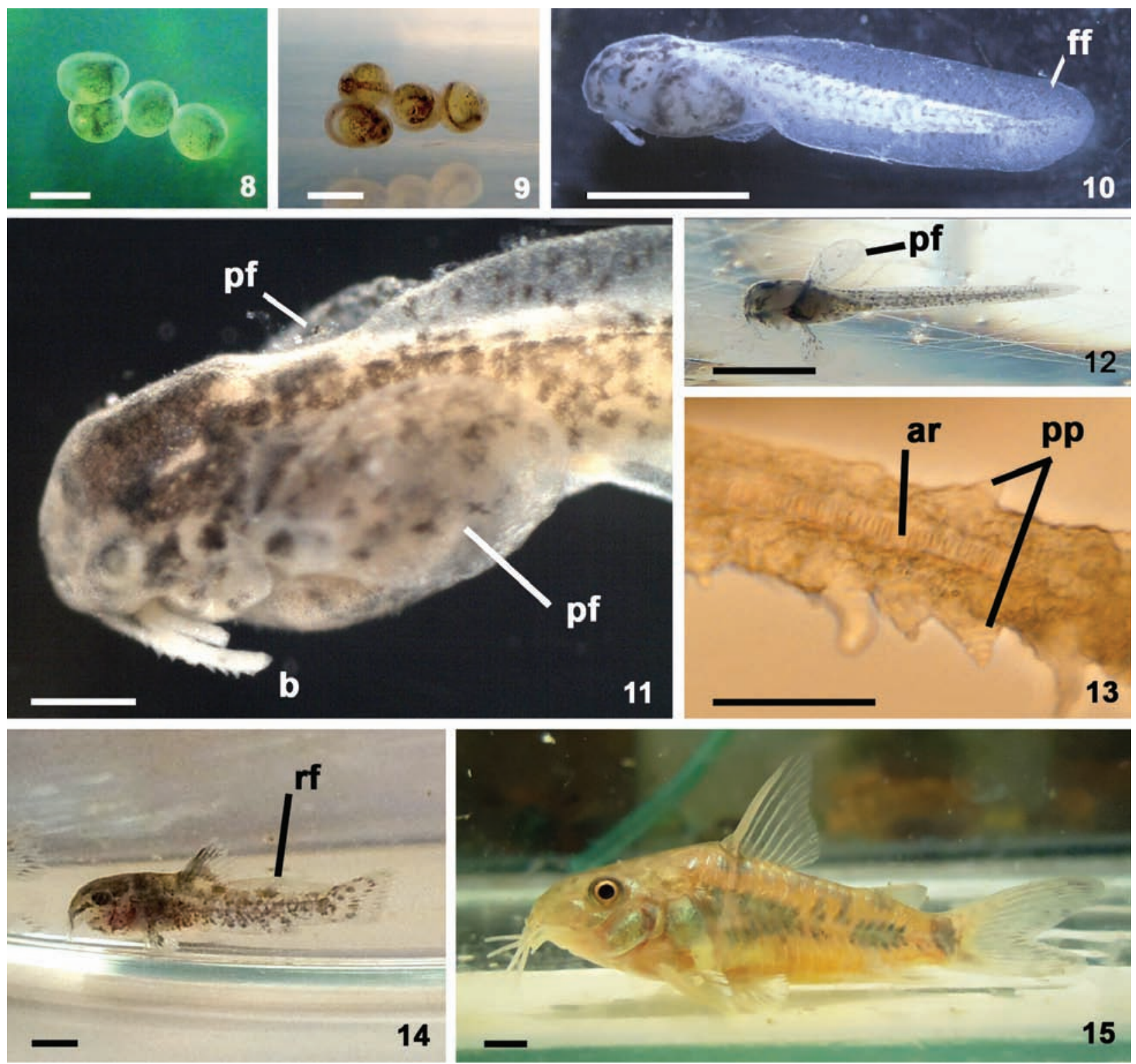

Figs 8-15. Corydoras aff. paleatus (Jenyns, 1842) development: 8, eggs with embryos of 4 days post-fertilization (dpf); 9, eggs with embryos at 5 dpf; 10, eleutheroembryo at $5.4 \mathrm{dpf}, 6.1 \mathrm{~mm} \mathrm{SL}$; 11, same specimen as in Fig. 10 at higher magnification; 12, protopterygiolarvae of 9 dpf, ventral view; 13, barbel segment from pterygiolarvae of $14 \mathrm{dpf}$; 14, late pterygiolarvae of $27 \mathrm{dpf}$; 15, young adult (ar, barbel axial rod; b, barbel; ff, median finfold; pf, pectoral finfold; pp, barbel pyramidal projection; rf, remaining median finfold). Scale bars, Figs 8, 9, 10, 12, 14, 15: 2 mm; Fig. 11: 400 $\mu \mathrm{m}$; Fig.13: $200 \mu \mathrm{m}$.

Tab. II. Values (\%) of minimal (Min), maximal (Max), mean (x) and standard deviation (SD) found for relationships between morphometrics variables (ED, eye diameter; HD, head depth; HL, head length; POD, preorbital distance) with respect to head length (HL) and/or standard length (SL) obtained from groups of individuals (n, number of analyzed specimens) of Corydoras aff. paleatus (Jenyns, 1842) at a given developmental phase (EE, eleutheroembryo; PP, protopterygiolarval phase; IPL, initial pterygiolarval phase; LPL, late pterygiolarval phase). Absence of data in some columns is due to incomplete development.

\begin{tabular}{|c|c|c|c|c|c|c|c|c|}
\hline & $\begin{array}{l}\mathrm{EE} \\
4.3-8.8 \mathrm{dpf} \\
\mathrm{n}=10\end{array}$ & & $\begin{array}{l}\text { PPL } \\
8.9-10.9 \mathrm{dpf} \\
\mathrm{n}=8\end{array}$ & & $\begin{array}{l}\text { IPL } \\
11-15 \mathrm{dpf} \\
\mathrm{n}=5\end{array}$ & & $\begin{array}{l}\text { LPL } \\
16-33 \mathrm{dpf} \\
\mathrm{n}=5\end{array}$ & \\
\hline Relationships (\%) & Min/Max & $\mathrm{x} \pm \mathrm{SD}$ & Min/Max & $\mathrm{x} \pm \mathrm{SD}$ & Min/Max & $\mathrm{x} \pm \mathrm{SD}$ & Min/Max & $\mathrm{x} \pm \mathrm{SD}$ \\
\hline $\mathrm{POD} / \mathrm{HL}$ & $13-33$ & $25.0-6.3$ & $16-24$ & $23.0-2.9$ & $34-41$ & $35.0-3.1$ & $36-47$ & $42.0-4.4$ \\
\hline $\mathrm{ED} / \mathrm{HL}$ & $15-38$ & $24.5-8.2$ & $29-31$ & $30.0-0.7$ & $16-43$ & $20.0-11.0$ & $18-46$ & $20.0-10.5$ \\
\hline $\mathrm{HD} / \mathrm{SL}$ & $15-24$ & $16.0-3.4$ & $19-20$ & $20.0-0.4$ & $26-26$ & $26.0-0.1$ & $22-30$ & $25.0-2.9$ \\
\hline HL/SL & $8-24$ & $11.0-4.5$ & $17-18$ & $18.0-0.4$ & $26-28$ & $27.0-0.8$ & $21-26$ & $23.0-1.6$ \\
\hline
\end{tabular}




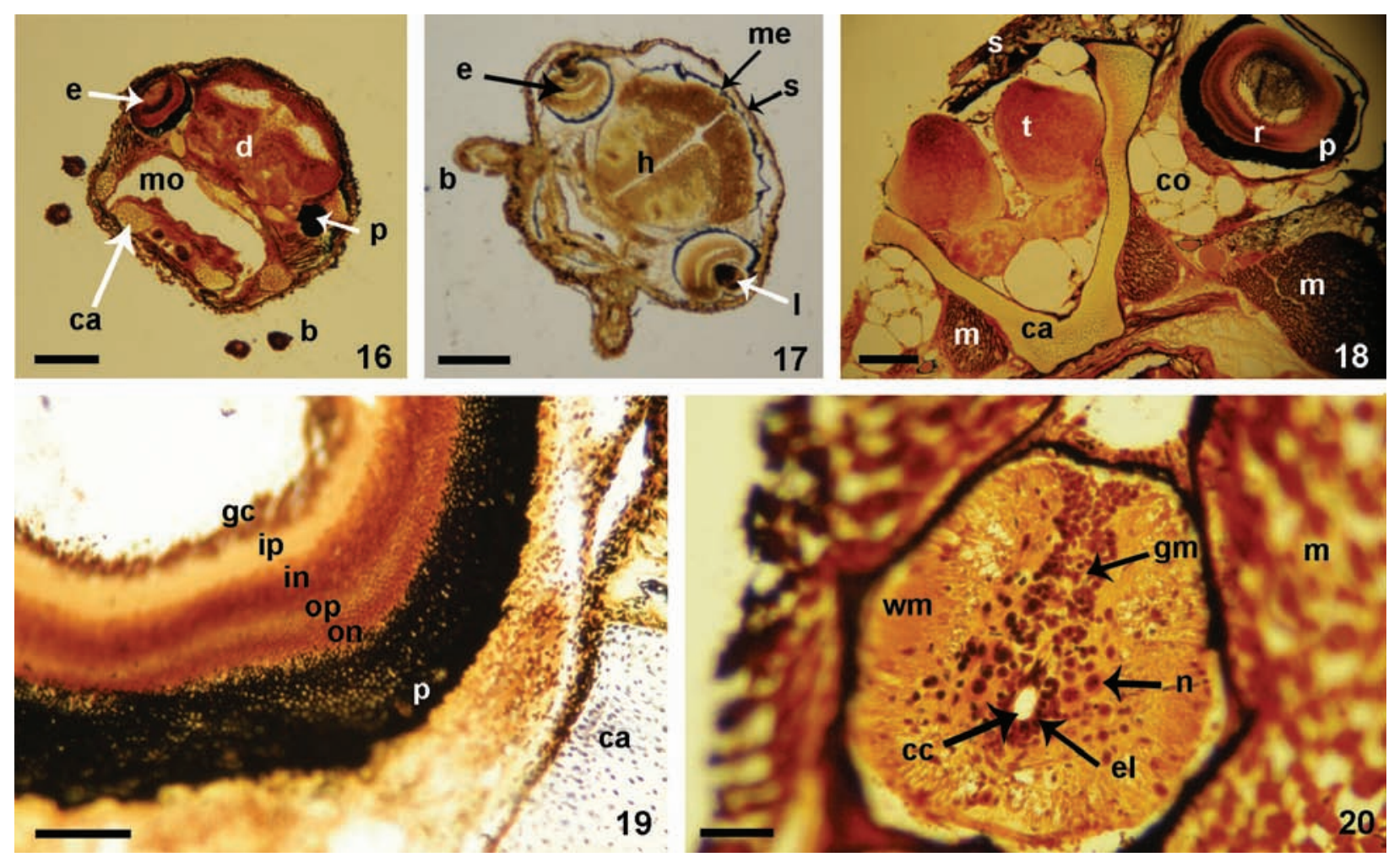

Figs 16-20. Coronal histological sections from decalcified, silver-impregnated specimens of Corydoras aff. paleatus (Jenyns, 1842): 16, protopterygiolarvae of 9.4 days post-fertilization (dpf); 17, pterygiolarvae of 12 dpf; 18, late pterygiolarval phase, 32 dpf; 19, sector of retina and orbit from a late pterygiolarvae of $32 \mathrm{dpf}$; 20, spinal cord from the same pterygiolarvae as in Fig. 19 (b, barbel; ca, cartilaginous tissue; cc, central canal; co, connective tissue; d, diencephalon; e, eye; el, ependymal lining; gc, ganglion cell layer; gm, grey matter; in, inner nuclear layer; ip, inner plexiform layer; l, lens; m, muscle; me, meninges; mo, mouth; n, neuron; on, outer nuclear layer; op, outer plexiform layer; p, pigmentary layer of retina; s, skin; t, telencephalon; wm, white matter). Scale bars, Figs 16, 17 and 18: $300 \mu \mathrm{m}$; Fig. 19: $10 \mu \mathrm{m}$; Fig. $20: 50 \mu \mathrm{m}$.

Tab. III. Corydoras aff. paleatus (Jenyns, 1842) organ and tissue differentiation as shown by stereomicroscopy and histological analysis. The left column shows developmental stages (EE, eleutheroembryo; PP, protopterygiolarval phase; PL, pterygiolarval phase), time period (dpf; days postfertilization) and length range (SL, standard length) encompassed; the middle column describes anatomical characteristics and the right column shows histological structure and differentiation of sensory organs and related central nervous system areas.

\begin{tabular}{lll}
\hline Period or phase & Anatomy and stereomicroscopy & Histology of sense organs and central nervous system \\
\hline EE & Yolk sac present & Barbelar mechano-receptors present \\
$4.3-8.8 \mathrm{dpf}$ & Small face & Moderatedly differentiated inner ear's hair cells \\
$4.3-6.4 \mathrm{~mm}$ & Two pairs of barbels & No layer segregation at retina and brain areas \\
& Unpigmented small eyes &
\end{tabular}

PP

8.9-10.9 dpf

$6.5-6.7 \mathrm{~mm}$

Mouth and anus open

Yolk sac disappearing

Finfold-type pectoral appendages

PL

11-33 dpf

6.8-10.7 mm
Highly vascularized external gills Pectoral appendages with radii

Three pairs of barbels Dermal scutes developing
JP

34-60 dpf

10.8.-18.0 mm
Temporary fin folds fully replaced by definitive fins
Eye lens forming

Highly differentiated inner ear hair cells

Rhombencephalon shows maximal differentiation among brain areas Mauthner cells receive several synapses

Barbelar pyramidal projections present

\section{Cartilaginous cranial bones}

Differentiated muscular tissue

Developed quimioreceptors

Increased cytoarchitectural complexity of cortical brain areas

Highly differentiated giant Mauthner cells receive hundreds of giant synaptic terminals (32 dpf)

Cortical cytoarchitectonics similar to adults (32 dpf)

Differentiated stellate spinal neurons (32 dpf)

All retinal layers recognizable (32 dpf)

Fully developed lateral line system

Brain cytoarchitectonics similar to adults 
completely reabsorbed yolk sac (Tabs I, III). At 15-16 dpf, the first radii appear at pectoral appendages, marking the commencement of the final step of pterygiolarval phase (Figs 5-7). At 27 dpf, the finfold looked thinner (Figs 6, 14) whereas adipose and anal fin profiles were distinguishable inside it. At $33 \mathrm{dpf}$, all fins were fully detached, except the adipose one, and histological analysis demonstrated ossification of the axial skeleton, whereas main parts of all cephalic bones are still constituted by cartilage (Figs 18, 19).

At juvenile period, from 34 to $60 \mathrm{dpf}$, all fins were fully differentiated and most temporary organs had been replaced by definite ones (Fig. 7). This may occur between 43 and $50 \mathrm{dpf}$. The first bony dermal plates or scutes, typical for Callichthyidae, started developing in connection with development of lateral line system channels.

Sensory areas and brain development. At the eleutherembryonic phase, eyes were small (Tab. I) and devoid of pigment (Figs 2, 10, 11). Future retinas and most brain regions remain thin and undifferentiated (Tab. III). In contrast, at seven dpf, a remarkable increase in differentiation of barbel (Fig. 13) and inner ear mechanoreceptors occurs, as in utricular and saccular maculi (Tab. III).

During the protopterygiolarval phase eyes diameter duplicate, growing from $0.21 \pm 0.04 \mathrm{~mm}$ in the eleutheroembryo to $0.38 \pm 24 \mathrm{~mm}$ in the early pterygiolarvae (see Tab I). Simultaneously, histological analysis locate eye pigments at the future pigmentary layer (Figs 2, 16) and demonstrate that diencephalic and retinal cytoarchitectonics continued exhibiting scarce development of synaptic neuropil layers (Fig. 17, Tab. III). Mauthner cells were easily recognizable and received synaptic contacts, as shown by our histological sections of silver impregnation methods.

At the pterygiolarval phase (11-33 dpf), retina and all cortical brain areas underwent remarkable progress in morphogenesis, as denoted by nuclear and cortical cytoarchitectural differentiation of the central nervous system (Figs 18-20) (Tab. III). At the end of this phase, all retinal layers were recognizable in histological sections (Fig. 19). Brain morphogenesis underwent considerable progress with respect to previous phase, while rhombencephalic structures continued to lead brain differentiation (Tab. III). Giant Mauthner cells, for instance, showed structural differentiation close to that found in the adult brain and received numerous afferent "giant" terminals on their surface. At the level of the spinal cord, silver impregnation methods evidenced the relative advancement in development of the grey matter in comparison to former phases. This included the presence of polygonal neuronal perikarya in the spinal grey matter (Fig. 20) some of them receiving numerous synaptic profile contacts, which where absent at the protopterygiolarvae (Tab. III).

Development of individual behavior. The appearance of sensory and locomotor capabilities and behaviors at different times upon fertilization is schematically shown in
Table II. The behavioral repertory of the just-hatched (5-6 dpf) eleutheroembryo is extremely limited. During the first $24 \mathrm{~h}$ post-hatching, they were usually still, supported by barbels and pectoral finfolds on the aquarium floor (see Tab. II). They rested most of the time hidden under objects or leaves, without interacting with its siblings. When moving, they did it alone. At "rest", the long and soft, wing-like pectoral appendages, moved alternatively with flag-like undulatory movement. Sometimes they exhibit "burst and coast swimming" behavior but, in addition, occasionally perform quicker, jerky, short (few centimeters) horizontal swimming, which during the first 20 or 30 post-hatching $h$ end frequently shocking obstacles (see Tab. II).

At the beginning of the pterygiolarval phase (11 dpf) larvae already demonstrate a perfect balance, quick swimming capacity and ability to stop suddenly in front of obstacles (Tab. IV). At 12 dpf, larvae responded readily to visual, auditive and hydromechanical stimuli, they were able of rapid negative reotropism, both in anteroposterior and lateral directions to oppose water movement or vibration. They executed spontaneous - in the absence of detectable external stimuli - horizontal swimmings, as well as slanting, ascending swimming that reach the water surface. Upon some of these ascending swimming some larvae executed their first recorded aeration behavior. Due to space reasons, further evolution of Corydoras paleatus individual behavior is synthesized in Table IV.

Evolution of social behavior: aggregation, shoaling and schooling. From hatching to $10 \mathrm{dpf}$, no larval aggregations were seen, i.e., "maximal aggregation number" (MAN) equals 1 (Fig. 21). First social interactions appear at 11-12 dpf, i.e., at the beginning of pterygiolarval phase; initially, larvae appear still in the open space, frequently in pairs, at 1-body-length distance (Tab. IV). One day later

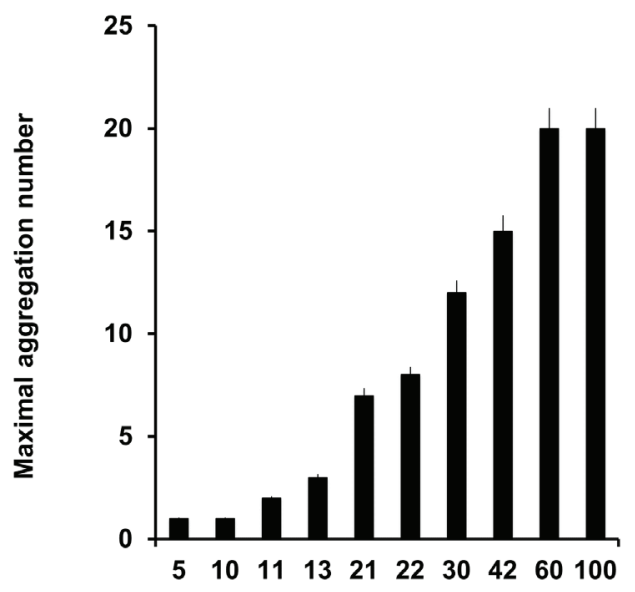

Age (days post-fertilization)

Fig. 21. Maximal aggregation size (MAS) as a function of fish age of Corydoras aff. paleatus (Jenyns, 1842). At different ages, from 5 to 100 days post-fertilization (dpf), the number of individuals present in each detected fish aggregation was computed. The maximal number of individuals recorded for each age, expressed as dpf was represented with a bar. Bar heights depict MAS as a function of age. 
Tab. IV. Age-dependent emergence of individual of Corydoras aff. paleatus (Jenyns, 1842) and social behavior during development. Individual movements and behaviors as well as spatial patterns of aggregations are described as a function of age (dpf, days post-fertilization) and growth (SL, standard length).

\begin{tabular}{|c|c|c|}
\hline Phase/Period & Age (dpf) & Behavior \\
\hline \multirow{6}{*}{$\begin{array}{l}\text { Eleutherembryonic phase } \\
4.3 \text { to } 6.4 \mathrm{~mm} \mathrm{SL}\end{array}$} & $4-7$ & Mostly immobile, hidden, alone still \\
\hline & $4-7$ & Photophobia \\
\hline & $4-7$ & Flag-like undulation of pectoral fin folds at rest \\
\hline & 5 & Anguilliform swimming \\
\hline & 5 & Freezing upon new stimuli \\
\hline & 6 & Occasional burst and coast swimming \\
\hline \multirow{3}{*}{$\begin{array}{l}\text { Protopterygiolarval phase } \\
6.5-6.7 \mathrm{~mm} \text { SL }\end{array}$} & 8.9 & External feeding begins \\
\hline & 9 & Exploratory behavior \\
\hline & 9 & Visually-triggered escape reflex \\
\hline \multirow{12}{*}{$\begin{array}{l}\text { Pterygiolarval Phase } \\
6.8-10.7 \mathrm{~mm} \text { SL }\end{array}$} & 11 & Pairs, still \\
\hline & $11-12$ & Perfect balance \\
\hline & 12 & Aeration behavior \\
\hline & 13 & Free swimming in horizontal direction \\
\hline & 13 & Few seconds of physical contact \\
\hline & 13 & Patrolling and foraging in pairs \\
\hline & 18 & Exploration and foraging on plants \\
\hline & 18 & Resting on elevated plant branches \\
\hline & 19 & Exploratory swimming in small shoaling groups \\
\hline & $20-33$ & Switch to carangiform swimming \\
\hline & 25 & Vertical swimming to surface and aeration \\
\hline & 26 & Foraging in small shoaling groups \\
\hline \multirow{4}{*}{$\begin{array}{l}\text { Juvenile period } \\
\text { 10.8-18.0 mm SL }\end{array}$} & 34 & Shoaling still \\
\hline & 34 & Foraging big shoaling groups \\
\hline & 34 & Schooling \\
\hline & 35 & Exploratory swimming along the walls up to the surface \\
\hline
\end{tabular}

(13 dpf), aggregations of three or four individuals were seen for the first time, and next days, group size gradually augment, as shown in Fig. 21. At 21 dpf, pterygiolarvae form aggregates exhibiting MAN of seven individuals, and the first shoals appear. The most frequent organization pattern is a loose still shoal (possible visual contact). From 22 to $100 \mathrm{dpf}$, they are frequently arranged as shoal still (Tab. IV) and the number of individuals integrating a shoal grows as age increases, from the first to the third month of life (see Fig. 21). Bi-dimensional (plane) foraging shoals of 6-10 individuals were seen after $40 \mathrm{dpf}$, and tri-dimensional foraging schools of up to 12 individuals after $60 \mathrm{dpf}$.

\section{DISCUSSION}

A first review of our Corydoras aff. paleatus growth curves shows that our samples reach mean SL sizes higher than those formerly published (Froese \& PAULY, 2013) and this may suggest that our work included the largest specimens ever reported. This may be due to the fact that our study follows lifetimes of specimens acquired in 2011 as well as their first generation of descendants, born at our laboratory, for almost three years. In our growth curves, SL seems to approach (asymptotically) to an apparent L Infinity $(L ¥)$ value close to $71 \mathrm{~mm}$, which would represent the maximum length of an infinitely old fish of the given stock (Froese \& BinOHLAN, 2000). Mean values included in our tables yolk sac diameters as a function of SL.

We have found some very remarkable developmental changes in relationships between body distances, as is the case of growth in eleutheroembryo's eye diameter or preorbital distance with respect to head length, which sometimes duplicate their size in a short time period, we were unable to demonstrate an allometric growth, a change which has been related to feeding adaptations that might mark a switch in developmental stage, as suggested by TAGUTI et al. (2009) for Pyrrhulina australis Eigenmann \& Kennedy, 1903 (Characiformes, Lebiasinidae). Another remarkable feature of larval period is the persistence of some embryonic organs which are later replaced by different definitive organs of similar function (HuYSENTRUYT et al., 2009). In Corydoras aff. paleatus, this sort of metamorphosis concentrates at the early, initial step of the pterygiolarval phase, when embryonic organs start to be not necessary anymore. This is the case of pectoral "wing-like" appendages, which are completely different from the definitive strong, ray-armed pectoral fins. The former is not supported by fin rays and can be viewed as a large skin fold. It has been suggested for Corydoras aeneus that the presence of these wing-like fins is very important 
to help reducing the lateral movement of the head during swimming movements (THorsten et al., 2004).

Comparative aspects. The stages in which we divided Corydoras aff. paleatus post-hatching ontogeny were comparable to those found in the related species Corydoras aeneus (Gill, 1858) by HuYsentruyt et al. (2009), although the former exhibits a slightly more protracted development, at least at temperatures used by us. This makes $C$. aeneus and $C$. aff. paleatus easily comparable to each other, adding heuristic value to our data. Post-hatching development of Siluriformes has deserved many studies which illustrate a wide variety of developmental adaptation strategies, from species without true larval phases (Lima et al., 2012) to other exhibiting many post-hatching phases, similar to the species of our study, as shown in the cascadu, Hoplosternum littorale (Hanckock, 1828) by RAMnARINE et al. (1994). Taking into account exclusively the Pimelodidae family, a great variety of developmental stages, phase names and incubation times can be found, including hatching times as short as 14-16 $\mathrm{h}$ as reported by Buzollo et al. (2011) and Nogueira et al. (2012), $30 \mathrm{~h}$ (Pereira et al., 2006), $50 \mathrm{~h}$ (Honji et al., 2012) and extremely prolonged incubations, as found in some marine catfishes (LimA et al., 2012). It is generally accepted that in most teleosts, larger eggs will produce, as a rule, larger larvae with larger yolk sacs and therefore, more developed organisms at hatching (SANCHES et al., 1999). In Characiformes, species having small oocytes present short incubation periods and consequently, very limited development at hatching time (Oliveira et al., 2012). For that reason, it is very interesting that Corydoras aff. paleatus, although produce small (not guarded) eggs, and eleutheroembryos looking at hatching structurally and functionally very immature, quickly starts external feeding and yolk sac absorption.

Development of sensory systems. Our data show that during the first days after hatching, while eyes are undifferentiated, facial isolated mechanoreceptive neuromasts, barbelar and inner ear mechanoreceptors, plus facial and barbelar chemoreceptors are the systems developing at higher pace. Photophobia, isolation and hiding from predation are important characteristics of this phase, which impose that energy accumulated in the yolk sac is almost not employed in locomotion, but mainly directed to morphogenetic and differentiation processes, very intense during these early life stages (VAN SNIK et al., 1997). Rapid morphogenesis and differentiation are necessary for developing the sensory, motor and reflex circuits essential for basic survival in the open aquatic environment where larvae will seek for external nutrients, as to assure that growth will be optimized to increase fitness (FuKUHARA, 1992).

Advanced protopterygiolarvae has already well developed inner ear mechanoreceptors and a set of mechanoreceptive free neuromasts, necessary not only for balance and swimming, but also for allowing adequate reflex defensive responses against predators. In connection with this, larvae show well developed Mauthner cells and circuits, which are necessary for the C-start or Mauthner reflex, fundamental for larval survival (KALUEFF et al., 2013), whereas rhomboencephalon and spinal cord lead neural differentiation. The visual system accelerates its differentiation during the proptoterygiolarval phase, but is only at the pterygiolarval phase when all retinal layers become recognizable. Morphological development of their respective systems suggest that this is a step of increase in the efficacy of respiratory, digestive and hydrodynamic structures. At the pterygiolarvae, priorities change towards osteomuscular development.

The rhombencephalon was the brain region showing major advances in differentiation, in line to balance and swimming control.

Behavioral changes. Swimming mode is also dependent on developmental age. It switches from the anguilliform to the carangiform mode. Carangiform and vertical swimming appear to be relevant for gaining higher swimming efficacy, necessary for the high level of social interaction typical of this species. Ascending swimming is necessary for aeration behavior, recorded for the first time it was similar to the behavior described in the adult by BuRGESS (1989).

As our data show, social behavior, expressed as maximal aggregation number and group cohesion also increase with age. At the end of the protopterygiolarval phase, simple resting and loose foraging aggregations are seen. Resting and foraging shoals grow in complexity and number of participants during pterygiolarval phase, but particularly during juvenile period. Social behavior is a complex phenomenon whose biological mechanisms and development are not well understood in vertebrates, but there is in general agreement that shoaling and schooling behavior are beneficial for the participating individuals (BUSKE \& GerLaI, 2011). Fishes benefit from shoal membership through increased hydrodynamic efficiency, and augmented security and foraging success (Pitcher \& PARRISH, 1993). Some studies have devoted attention to development of behavior and sensory organs in Siluriformes (KHODA et al., 1995; Pruzsinszky \& Ladich,1998; Maguit et al., 2010; Mukai et al., 2010; Raнmaн et al., 2011) but we believe this is the first study demonstrating developmental changes in aggregation size and in shoaling behavior in Corydoras aff. paleatus.

Concluding remarks and perspectives. As a whole, our study suggests that Corydoras aff. paleatus ethodevelopmental evolution exhibits a strong correlation with phases of morphological development that we have described. Overall, we believe that our study may represent an useful departure point for future integrative analysis of correlative development. However, much more detailed studies on ontogeny of $C$. aff. paleatus neuroanatomy and behavior will be necessary before establishing a more definitive and heuristic correlation between structure, function and behavior of this species. Finally, since longterm breeding under artificial conditions could affect early 
development, a projection of the results of this study onto the whole species should be considered with caution.

Acknowledgements. The authors are grateful to PEDECIBA Postgraduate Program (Biology) for supporting M.Sc. studies of GdP and for continued financial support to DRI's laboratory. We are indebted to Luis Pérez Córdova for his invaluable help with photography of living specimens. We wish to thank Mario Lalinde and Joaquín Carrique for help with illustrations, and Andrea Etchartea and Alicia Soza for help with specimen measurement and photography.

\section{REFERENCES}

Baigún, C.; López, G.; Dománico, A.; Ferriz, R.; Sverlij, S. \& Delfino SCHENKE, R. 2002. Presencia de Corydoras paleatus (Jenyns, 1842), una nueva especie brasílica en el Norte de la Patagonia (Río Limay) y consideraciones ecológicas relacionadas con su distribución. Ecología Austral 12:41-48.

BALON, E. K. 1975. Terminology of intervals in fish development. Journal of the Fisheries Research Board of Canada 32:1663-1670.

1999. Alternative ways to become a juvenile or a definitive phenotype (and on some persisting linguistic offenses. Environmental Biology of Fishes 56:17-38.

Belanger, S. E.; Balon, E. K. \& Rawlings, J. M. 2010. Saltatory ontogeny of fishes and sensitive early life stages for ecotoxicology tests. Aquatic Toxicology 97:88-95.

BritTo, M. R. 2003. Phylogeny of the subfamily Corydoradinae Hoedeman, 1952 (Siluriformes: Callichthyidae), with a definition of its genera. Proceedings of the Academy of Natural Sciences of Philadelphia 153:119-154.

Burgess, W. E. 1989. Family Callichthyidae (Armored Catfish). In: Red, R. ed. An Atlas of Freshwater and Marine Catfishes. A Preliminary Survey of the Siluriformes. Neptune City, T.F.H. Publications. p.326-367.

Buske, C. \& Gerlai, R. 2011. Shoaling develops with age in zebrafish (Danio rerio). Progress in Neuro-Psychopharmacology \& Biological Psychiatry 35:1409-1415.

Buzollo, H.; Veríssimo-Silveira, R.; Oliveira-Almeida, I. R.; Alexandre, J. S.; OKudA, H. T. \& Ninhaus-SiLveiRA, A. 2011. Structural analysis of the Pimelodus maculatus (Lacépède, 1803) embryogenesis (Siluriformes: Pimelodidae). Neotropical Ichthyology 9(3):601-616.

Cazenave, J.; Bistoni, M. A.; Pesce, S. F. \& Wunderlin, D. A. 2006. Differential detoxification and antioxidant response in diverse organs of Corydoras paleatus experimentally exposed to microcystin-RR. Aquatic Toxicology 76:1-12.

de Castilhos Ghisi, N. \& Cestari, M. M. 2013. Genotoxic effects of the herbicide Roundup $\left({ }^{\circledR}\right)$ in the fish Corydoras paleatus (Jenyns 1842) after short-term, environmentally low concentration exposure. Environmental Monitoring and Assessment 185(4):3201-3207.

Durán, I.; Marí-Beffa, M.; Santamaría, J. A.; Becerra, J. \& SantosRuiz, L. 2011. Actinotrichia collagens and their role in fin formation. Developmental Biology 354:160-172.

Ferraris JR., C. J. 2007. Checklist of catfishes, recent and fossil (Osteichthyes: Siluriformes), and catalogue of siluriform primary types. Zootaxa 1418:1-300.

Froese, R. \& Binohlan, N. 2000. Empirical relationships to estimate asymptotic length, length at first maturity and length sat maximum yield per recruit in fishes, with a simple method to evaluate length frequency data. Journal of Fish Biology 56:758-773.

Froese, R. \& Pauly, D. 2013. Corydoras paleatus (Jenyns 1842) Peppered Corydoras. FishBase. World Wide Web electronic publication. Available at: $<$ http://www.fishbase.org/summary/Corydoras-paleatus. html>. Accessed on: 27 November 2013.

FuKUHARA, O. 1992. Study on the development of functional morphology and behaviour of the larvae of eight commercially valuable teleost fishes. Contributions to the Fisheries Researches in Japan Sea Block 25:1-122.

FulLER, I. A. 2001. Breeding Corydoradine Catfishes. Kidderminster, Ian Fuller Enterprises. 248p.
Guiloski, I. C.; Rossi, S. C.; da Silva, C. A. \& De Assis, H. C. 2013. Insecticides biomarker responses on a freshwater fish Corydoras paleatus (Pisces: Callichthyidae). Journal of Environmental Science and Health, Part B 48(4):272-277.

Honj, R. M.; Tolussi, C. E.; Mello, P. H.; Caneppele, D. \& Moreira, R. G. 2012. Embryonic development and larval stages of Steindachneridion parahybae (Siluriformes: Pimelodidae): implications for the conservation and rearing of this endangered Neotropical species Neotropical Ichthyology 10(2):313-327.

Huysentruyt, F.; Moerkerke, B.; Devaere, S. \& Adrieaens, D. 2009. Early development and allometric growth in the armored catfish Corydoras aeneus (Gill,1958). Hydrobiology 627:45-54.

KaluefF, A. V.; Gebhardt, M.; Stewart, A. M.; Cachat, J. M.; Brimmer, M.; Chawla, J. S.; Craddock, C.; Kyzar, E. J.; Roth, A.; Landsman, S.; Gaikwad, S.; Robinson, K.; BaAtrup, E.; Tierney, K.; ShamchuK, A.; Norton, W.; Miller, N.; Nicolson, T.; Braubach, O.; Gilman, C. P.; Pittman, J.; Rosemberg, D. B.; Gerlai, R.; Echevarria, D.; Lamb, E.; Neuhauss, S. C.; Weng, W.; Bally-Cuif, L. \& Schneider, H. 2013. Towards a comprehensive catalog of zebrafish beahavior 1.0 and beyond. Zebrafish 10(1):70-86.

Kapoor, B. G. \& Khanna, B. 2004. Ichthyology Handbook. New Delhi, Springer. 1072p.

Khoda, M.; Tanimura, M.; Kikue-Nakamura, M. \& Yamagishi, S. 1995. Sperm drinking by female catfishes: a novel mode of insemination. Environmental Biology of Fishes 43:1-6.

Kovács, V.; Copp, G. H. \& Francis, M. P. 1999. Morphometry of the stone loach Barbatula barbatula: do mensural characters reflect the species' life history thresholds? Environmental Biology of Fishes 56:105-115.

Kramer, D. L. \& McClure, M. 1980. Aerial respiration in the catfish, Corydoras aeneus (Callychhthydae). Canadian Journal of Zoology 58:1984-1991.

Lima, A. R. A.; Barletta, M. ; Dantas, D. V.; Possato, F. E.; Ramos, J. A. A. \& CostA, M. F. 2012. Early development and allometric shifts during the ontogeny of a marine catfish (Cathorops spixii-Ariidae). Journal of Applied Ichthyology 28(2):217-225.

Maguit, Q.; Olivier, D.; Vandewalle, N. \& Vandewalle, P. 2010. Ontogeny of swimming movements in bronze corydoras (Corydoras aeneus). Canadian Journal of Zoology 88:378-389.

Mukai, Y.; Tuzan, A. D.; Shaleh, S. R. M. \& Manjaji-Matsumoto, B. M. 2010. Development of sensory organs and changes of behavior in the larvae of the sutchi catfish, Pangasianodon hypopthalmus. Fisheries Science 76:921-930.

Nogueira, L. B.; Azevedo, P. G.; Canelhas, M. R.; Bedore, A. G.; Lopes, J. M. \& GodinHo, H. P. 2012. Induced spawning and early ontogeny in hatchery-reared catfish Zungaro jahu (Siluriformes: Pimelodidae). Neotropical Ichthyology 10(1):89-98.

Novomeská, A.; Katina, S.; Copp, G. H.; Pedicillo, G.; Lorenzoni, M.; Pompei, L.; Coucherousset, J. \& KovÁcs, V. 2013. Morphological variability of black bullhead Ameiurus melas in four non-native European populations. Journal of Fish Biology 82:1103-1118

Oliveira, F. G.; Bialetzi, A.; Gomes, L. C.; Santin, M. \& Taguti, T. L. 2012. Desenvolvimento larval de Brycon hilarii (Characiformes, Characidae). Iheringia, Série Zoologia 102(1):62-70.

Pereira, C. R.; Barcellos, L. J. G.; Kreutz, L. C.; Quevedo, R. M.; Ritter, F. \& Silva, L. B. 2006. Embryonic and larval development of Jundiá (Rhambdia quelen, Quoy \& Gaimard, 1842, Pisces, Teleostei) a South American catfish. Brazilian Journal of Biology 66(4):1057-1063.

Pesce, S. E.; Cazenave, J.; Monferran, M. V.; Frede, S. \& Wunderlin, D. A. 2008. Integrated survey on toxic effects of lindane on neotropical fish: Corydoras paleatus and Jenynsia multidentata. Environmental Pollution 156:775-783.

Pistone, G.; Eguren, G. \& Rodriguez-Ithurralde, D. 2012. Inhibition, recovery and field responses of Astyanax fasciatus (Cuvier, 1819) brain cholinesterases upon exposure to azinphos-methyl. Ecotoxicology and Environmental Contamination 7(2):93-102.

Pitcher, T. J. 1983. Heuristic definitions of shoaling behavior. Animal Behavior 31:611-613. 
Pitcher, T. J. \& Parish, K. J. 1993. Functions of schoaling behavior in teleosts. In: Pitcher, J. J. ed. Behavior of teleost fishes. London, Chapman \& Hall. p.363-439.

PruzsinszKy, I. \& LADICH, F. 1998. Sound production and reproductive behavior of the armoured catfish Corydoras paleatus ( Callichthyidae). Environmental Biology of Fishes 53:183-191.

Rahmah, S.; Yamamoto, S.; Nakagawa, Y.; Kato, K.; Senoo, S. \& Murata, O. 2011. Development of morphology, sensory organs and behavior of larval bagrid catfish Mystus nemurus. Aquaculture Science 59(3):443-450.

RAMnARINE, I. W. 1994. Larval culture, development and growth of the cascade, Hoplosternum littorale (Hancock 1828; Callichthyidae). Aquaculture 126(9):291-298.

Ramón y Cajal, S. \& de Castro, F. 1972. Elementos de Técnica Micrográfica del Sistema Nervioso. Barcelona, Salvat. 283p.

ReIs, R. E. 2003. Family Callichthyidae (armored catfishes). In: REIS, R. E.; Kullander, S. O. \& Ferraris Jr., C. J. eds. Check List of the Freshwater Fishes of South and Central America. Porto Alegre, Edipucrs. p.291-309.

Rodriguez-IthurRalde, D.; Maruri, A. \& Rodríguez, X. 1998. Motor neurone acetylcholinesterase release precedes neurotoxicity caused by systemic administration of excitatory amino acids and strychnine. Journal of the Neurological Sciences 160(S1):S80-S86.

Sanches, P. V.; Nakatani, K. \& Bialetzki, A. 1999. Morphological description of the developmental stages of Parauchenipterus galeatus (Linnaeus, 1766) (Siluriformes, Auchenipteridae) on the floodplain of the upper Paraná River. Revista Brasileira de Biologia 59(3):429438.
SARIKAya, R.; Selvi, M. \& Erkoç, F. 2004. Investigation of acute toxicity of fenitrothion on peppered corydoras (Corydoras paleatus) (Jenyns, 1842). Chemosphere 56:697-700.

Shimabukuro-Dias, C. K.; Oliveira, C.; Reis, R. E. \& Foresti, F. 2004. Molecular phylogeny of the armored catfish family Callichthyidae (Ostariophysi, Siluriformes). Molecular Phylogenetics and Evolution 32:153-163.

SoKal, R. R. \& RohlF, F. J. 1981. Biometry. The principles and practice of statistics in biological research. New York, W. H. Freenan and Company. 859p.

Taguti, T. L.; Kipper, D.; Bialetzki, A.; Sanches, P. V.; CavicchioliMakrakis, M.; Baumgartner, G.; Fernandes, R.; Fernandes, G. \& EARLY, R. 2009. Desenvolvimento inicial de Pyrrhulina australis Eigenmann \& Kennedy, 1903 (Characiformes, Lebiasinidae). Biota Neotropica 9(4):59-65.

Tencatt, L. F. C..; Britto, M. R. \& Pavanelli, C. S. 2014. A new species of Corydoras Lacépède, 1803 (Siluriformes: Callichthyidae) from the upper rio Paraná basin, Brazil. Neotropical Ichthyology 12(1):89-96.

Thorsten, D. H.; Cassidy, J. J. \& Hale, M. E. 2004. Swimming of larval zebrafish: fin-axis coordination and implications for function and neural control. Journal of Experimental Biology 207(24):41754183.

Van Snik, G. M. J.; Van den Boogaart, J. G. M. \& Osse, J. W. M. 1997. Larval growth patterns in two ostariophysian fish (Cyprinus carpio and Clarias gariepinus) with attention to the finfold. Journal of Fish Biology 50:1339-1352. 